\title{
Vertical distribution and abundance of juvenile cephalopods in the Aegean Sea*
}

\author{
ALP SALMAN $^{1}$, TUNCER KATAĞAN ${ }^{1}$, H. AVNI BENLI' ${ }^{2}$ \\ ${ }^{1}$ Ege University Fisheries Faculty Department of Hydrobiology 35100 Bornova, İzmir Türkiye. \\ 2 Dokuz Eylül University Marine Science and Technology Institute Inciraltı, Izmir Türkiye.
}

\begin{abstract}
SUMMARY: This study was carried out in northern (Saros Bay) and southern (Gökova Bay) parts of the Aegean Sea. In pelagic samplings, Hamburg Plankton Net (HPN) was used. Samplings were done out at four different periods of a 24 hour day; sunrise, noon, sunset and midnight. Horizontal hauls were carried out at depths of 100, 350 and $650 \mathrm{~m}$. As the result of 24 hauls in both parts of the Aegean Sea, one hundred juvenile specimens were sampled and 14 species were determined. Juvenile cephalopods were mostly frequent at $350 \mathrm{~m}$. Among the determined species, Chtenopteryx sicula (Verany, 1851), Brachioteuthis riisei (Steenstrup, 1882), Illex coindetii (Verany, 1839), Thysanoteuthis rhombus Trochel, 1857 and Argonauta argo Linnaeus, 1798 juveniles are being reported for the first time in the Aegean Sea. $28 \%$ of the catches were from the northern Aegean and the remaining $72 \%$ were from the southern Aegean. Heteroteuthis dispar (Rüppell, 1844) was the most common species.
\end{abstract}

Key words: Cephalopoda, juvenile, vertical distribution, Aegean Sea.

RESUMEN: DisTRIBUCIÓN VERTICAL Y ABUNDANCIA DE JUVENILES DE CEFALÓPODOS DEL MAR EGEO. - El presente estudio se llevó a cabo en la zona norte del Mar Egeo (Bahía de Saros) y en la zona sur (Bahía de Gökova) de dicho mar. Para los muestreos pelágicos se usó la red de plancton Hamburg Plankton Net (HPN). Los muestreos se llevaron a cabo en cuatro momentos diferentes en un periodo de 24 horas: amanecer, mediodía, atardecer y medianoche. Se realizaron arrastres horizontales a profundidades de 100, 350 y $650 \mathrm{~m}$. Se capturaron cien cefalópodos juveniles pertenecientes a 14 especies como resultado de los 24 arrastres realizados en ambas áreas del mar Egeo. Los cefalópodos juveniles fueron mas frecuentes a 350 $\mathrm{m}$ de profundidad. Entre las especies determinadas fueron citadas por primera vez en el mar Egeo los juveniles de: Chtenopteryx sicula (Verany, 1851), Brachioteuthis riisei (Steenstrup, 1882), Illex coindetii (Verany, 1839), Thysanoteuthis rhombus Trochel, 1857 y Argonauta argo Linnaeus, 1798. El $28 \%$ de las capturas provinieron del Egeo septentrional y el resto, $72 \%$, del Egeo meridional. Heteroteuthis dispar (Rüppell, 1844) fue la especie más común.

Palabras clave: Cephalopoda, juveniles, distribución vertical, mar Egeo.

\section{INTRODUCTION}

Because of its differing ecologic characteristics, which are reflected in its biological characteristics, the Aegean Sea is divided into northern and southern subsections. There are trenches with depths of more then $3150 \mathrm{~m}$ in the south but the deepest

\footnotetext{
*Received January 9, 2002. Accepted October 18, 2002.
}

trench in the study basin was no deeper than 1000 $\mathrm{m}$. The average depth is around $350 \mathrm{~m}$ (Kocatas and Bilecik, 1992).

In the life cycle of the pelagic ecosystem, juveniles of benthic cephalopods play as important a role in food-predator relationships as the juveniles of pelagic cephalopods (Amaratunga, 1983). Studies on the distribution of pelagic cephalopods in the Mediterranean have been carried out by Naef 
(1923), Degner (1925), Mangold-Wirz (1963), Roper (1974), Sánchez and Molí (1985), Bello (1986, 1990) and Orsi-Relini et al. (1994).

In the Aegean Sea, a mesopelagic young fish trawl was used for the first time by the Danish Oceanographical Expedition to the Mediterranean and adjacent seas. At that time, Degner (1925) sampled some species of juvenile cephalopods. Nine other juvenile cephalopod species have more recently been reported by Lefkaditou et al. (1999), who studied the mesopelagic fauna in the northern Aegean.

In contrast with the inadequacy of studies on juvenile cephalopods, there have been several studies on the distribution and biology of adults by Katagan and Kocatas (1990), D'Onghia et al. (1991, 1996), Katagan et al. (1992), Salman et al. (1997, 2000), Stergiou et al. (1997).

When the information above is considered, it is observed that there are not many studies on juvenile cephalopods in the Aegean Sea. With this study we aimed to investigate the vertical distribution and abundance of juvenile cephalopods according to different periods of the 24-hour day.

\section{MATERIAL AND METHODS}

This study was carried out in the Aegean Sea in the period May 10-24 2001 by the R/V K. Piri Reis. For pelagic sampling a $0.5 \mathrm{~mm}$ mesh size Hamburg Plankton Net (HPN; Isaac-Kid, modified from mid-water trawl, Hydrobios) was used. Sampling was done down to a depth of $850 \mathrm{~m}$ in the Saros Bay region (north) and down to a depth of $714 \mathrm{~m}$ in the Gökova Bay region (south) (Fig. 1). In order to determine the vertical distribution of cephalopods according to the amount of light, samplings in both directions were performed during four different periods of day time (dawn, noon, dusk, midnight) and at depths of 100, 350 and $650 \mathrm{~m}$.

A total of 24 hauls were carried out as one set of 12 at each station. Depths at which hauls were carried out were recorded by a Scanmar depth sensor. A fifteen-minute horizontal haul was carried out at each depth. The hauling speed was stabilized at 3.5 knots. Samples were preserved in $4 \%$ formalin in seawater.

Dorsal mantle lengths (ML) of preserved specimens were measured. To identify specimens, a stereomicroscope (Olympus model SZ-60) was used for

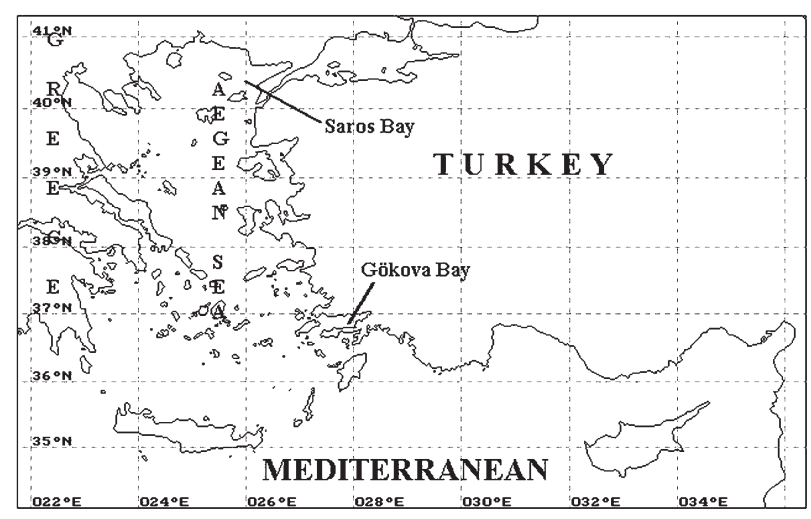

FIG. 1. - Sampling area.

photographing and a camera lucida was used for drawings. For statistical calculation Tukey one way variance analysis (Sokal and Rohlf, 1980) was used. The juvenile cephalopods were identified according to keys of Chun (1910), Naef (1923), and Sweeney et al. (1992).

\section{RESULTS}

One hundred juvenile cephalopod specimens were collected from 21 of 24 hauls. Among this catch 14 species, 13 genera and 13 families were included. The number of species recorded was 10 in the north and 8 in south (Table 1). Species of which juveniles are reported in the Aegean Sea for the first time are marked with an asterisk (Table 1).

Remarks on each species are given below following the systematic order of Sweeney and Roper (1998).

\section{Order SEPIOLIDA \\ Subfamily HETEROTEUTHIDINAE Heteroteuthis dispar (Rüppell, 1844)}

This was the most abundant species in both parts of the study area (Aegean Sea), comprising $50 \%$ of total cephalopod species in the northern Aegean and $41.7 \%$ in the southern Aegean. It was observed at all depths and time periods all over the Aegean Sea. (Table 1, 2). ML of 44 specimens from $H$. dispar varied between 0.9-9.1 $\mathrm{mm}$. When their sizes were examined in groups of catch depths as the result of Tukey one-way variance analysis $\left[\mathrm{F}_{\text {calc }}=\right.$ 3.35 critical $\mathrm{F}_{0.05}(2.41)=3.22$ ] it was found that longer specimens were spread within 100-350 metres and smaller specimens were spread within 350-650 metres (Fig. 2). 
TABLE 1. - List of cephalopod juveniles caught at different depth levels

\begin{tabular}{|c|c|c|c|c|c|c|c|c|}
\hline \multirow[b]{2}{*}{ Species } & \multicolumn{2}{|c|}{$100 \mathrm{~m}$} & \multicolumn{2}{|c|}{$350 \mathrm{~m}$} & \multicolumn{2}{|c|}{$650 \mathrm{~m}$} & \multicolumn{2}{|c|}{ Total } \\
\hline & $\mathrm{N}$ & $\%$ & $\mathrm{~N}$ & $\%$ & $\mathrm{~N}$ & $\%$ & $\mathrm{~N}$ & $\%$ \\
\hline \multicolumn{9}{|l|}{ NORTH AEGEAN } \\
\hline Heteroteuthis dispar & 3 & 42.8 & 8 & 80.0 & 3 & 27.3 & 14 & 50.0 \\
\hline Pyroteuthis margaritifera & & & 1 & 10.0 & 3 & 27.3 & 4 & 14.3 \\
\hline Onychoteuthidae sp. & & & & & 1 & 9.1 & 1 & 3.6 \\
\hline Histioteuthis bonnellii & 1 & 14.3 & & & & & 1 & 3.6 \\
\hline Histioteuthis reversa & 2 & 28.6 & & & & & 2 & 7.1 \\
\hline *Chtenopteryx sicula & 1 & 14.3 & & & & & 1 & 3.6 \\
\hline *Illex coindetii & & & & & 2 & 18.2 & 2 & 7.1 \\
\hline *Thysanoteuthis rhombus & & & 1 & 10.0 & & & 1 & 3.6 \\
\hline Octopus vulgaris & & & & & 1 & 9.1 & 1 & 3.6 \\
\hline Eledone cirrhosa & & & & & 1 & 9.1 & 1 & 3.6 \\
\hline Total & 7 & 25 & 10 & 35 & 11 & 40 & 28 & 100 \\
\hline \multicolumn{9}{|l|}{ SOUTH AEGEAN } \\
\hline Heteroteuthis dispar & 3 & 21.4 & 17 & 54.8 & 10 & 37.1 & 30 & 41.7 \\
\hline Ancistrocheirus lesueurii & & & 1 & 3.2 & & & 1 & 1.4 \\
\hline Pyroteuthis margaritifera & 2 & 14.3 & 5 & 16.1 & 4 & 14.8 & 11 & 15.3 \\
\hline *Brachioteuthis riisei & & & 1 & 3.2 & & & 1 & 1.4 \\
\hline *Illex coindetii & 2 & 14.3 & & & 4 & 14.8 & 6 & 8.3 \\
\hline Chiroteuthis veranii & & & & & 1 & 3.7 & 1 & 1.4 \\
\hline Octopus vulgaris & 6 & 42.9 & 7 & 22.6 & 8 & 29.6 & 21 & 29.2 \\
\hline *Argonauta argo & 1 & 7.1 & & & & & 1 & 1.4 \\
\hline Total & 14 & 19 & 31 & 43 & 27 & 38 & 72 & 100 \\
\hline TOTAL (Aegean Sea) & 21 & 21 & 41 & 41 & 38 & 38 & 100 & 100 \\
\hline
\end{tabular}

TABLE 2. - Distribution of cephalopod juveniles caught in Aegean Sea considering period of light, depth and regions

\begin{tabular}{|c|c|c|c|c|c|c|c|c|c|c|c|c|}
\hline \multirow{2}{*}{$\begin{array}{l}\text { Time Period } \\
\text { Depth }(\mathrm{m})\end{array}$} & \multicolumn{3}{|c|}{ Dawn } & \multicolumn{3}{|c|}{ Noon } & \multicolumn{3}{|c|}{ Dusk } & \multicolumn{3}{|c|}{ Midnight } \\
\hline & 100 & 350 & 650 & 100 & 350 & 650 & 100 & 350 & 650 & 100 & & 650 \\
\hline \multicolumn{13}{|l|}{ NORTH AEGEAN } \\
\hline Heteroteuthis dispar & & & & & 2 & & 2 & 5 & & 1 & 1 & 3 \\
\hline Pyroteuthis margaritifera & & & & & & & & 1 & & & & 3 \\
\hline Onychoteuthidae sp. & & & & & & 1 & & & & & & \\
\hline Histioteuthis bonnellii & & & & & & & 1 & & & & & \\
\hline Histioteuthis reversa & 1 & & & & & & 1 & & & & & \\
\hline Chtenopteryx sicula & & & & 1 & & & & & & & & \\
\hline Illex coindetii & & & & & & 1 & & & & & & 1 \\
\hline Thysanoteuthis rhombus & & & & & & & & 1 & & & & \\
\hline Octopus vulgaris & & & & & & & & & & & & 1 \\
\hline Eledone cirrhosa & & & & & & & & & 1 & & & \\
\hline Total & 1 & & & 1 & 2 & 2 & 4 & 7 & 1 & 1 & 1 & 8 \\
\hline \multicolumn{13}{|l|}{ SOUTH AEGEAN } \\
\hline Heteroteuthis dispar & & 5 & 1 & 3 & 6 & 3 & & 2 & 2 & & 4 & 4 \\
\hline Ancistrocheirus lesueurii & & & & & & & & & & & 1 & \\
\hline Pyroteuthis margaritifera & 2 & 1 & & & & 1 & & & 1 & & 4 & 2 \\
\hline Brachioteuthis riisei & & & & & & & & & & & 1 & \\
\hline Illex coindetii & & & 2 & 2 & & & & & & & & 2 \\
\hline Chiroteuthis veranii & & & 1 & & & & & & & & & \\
\hline Octopus vulgaris & 1 & & & 2 & 1 & 3 & 3 & 1 & 2 & & 5 & 3 \\
\hline Argonauta argo & 1 & & & & & & & & & & & \\
\hline Total & 4 & 6 & 4 & 7 & 7 & 7 & 3 & 3 & 5 & & 15 & 11 \\
\hline TOTAL (Aegean Sea) & 5 & 6 & 4 & 8 & 9 & 9 & 7 & 10 & 6 & 1 & 16 & 19 \\
\hline
\end{tabular}




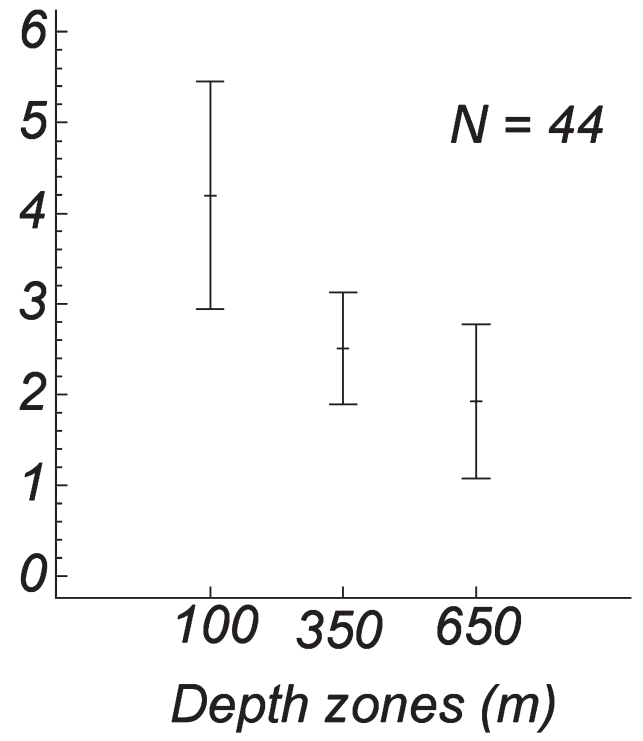

FIG. 2. - Size distribution of Heteroteuthis dispar according to depth by Tukey one-way variance analysis
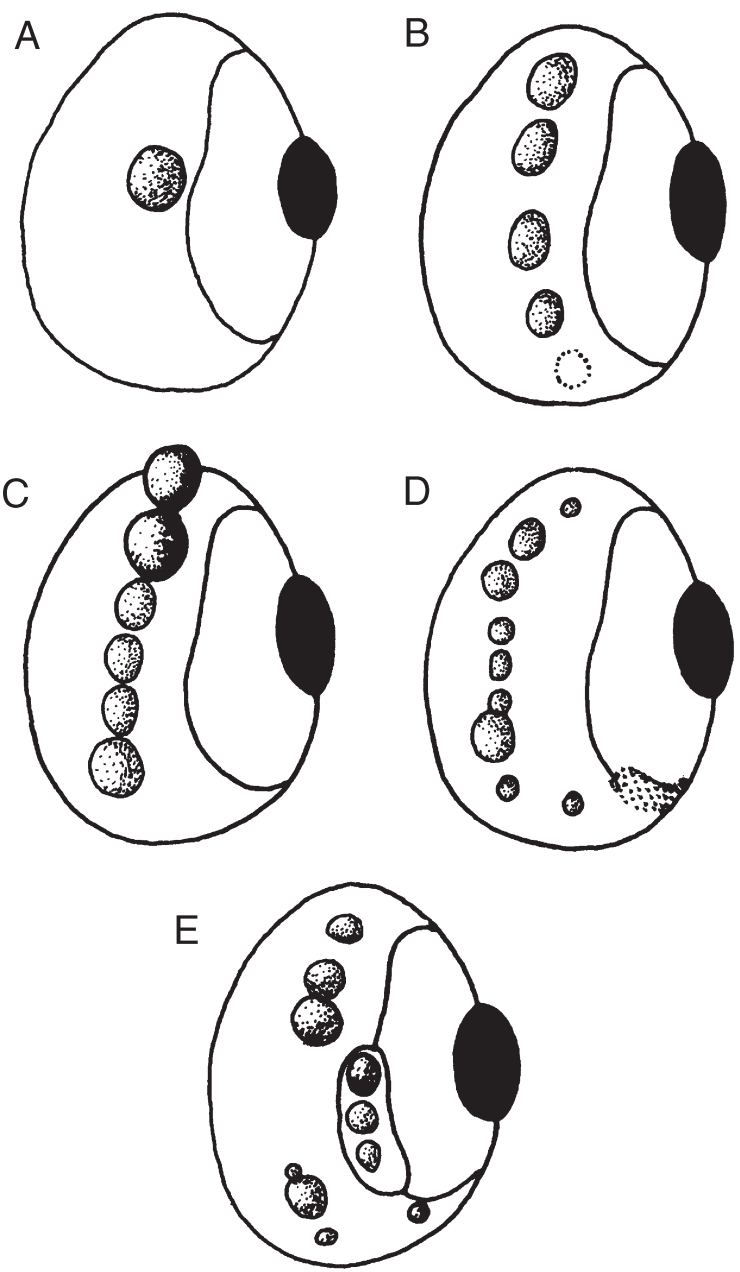

FIG. 3. - Ontogenic variances of eye photophores of Pyroteuthis margaritifera (A: $1.8 \mathrm{~mm}$ ML; B: 2.8-3.1 mm ML; C: $3.8-4.6 \mathrm{~mm}$ ML; D: $6.6 \mathrm{~mm}$ ML; E: $8.3 \mathrm{~mm} \mathrm{ML).}$
Order TEUTHIDA

Suborder OEGOPSINA

Family ANCISTROCHEIRIDAE

Ancistrocheirus lesueurii (Orbigny, 1842)

One specimen ( $2.5 \mathrm{~mm} \mathrm{ML})$ was retrieved from $350 \mathrm{~m}$ in the southern region (Table 1).

Family PYROTEUTHIDAE

Pyroteuthis margaritifera (Rüppell, 1844)

15 specimens of this species were sampled. Four individuals were collected from the northern Aegean at 350-650 m, measuring 3.5-6.6 $\mathrm{mm} \mathrm{ML}$; the other eleven with 1.8-16.6 mm ML were from the southern Aegean.

Within the specimens examined, anal photophores in the dorsal cavity were observed on ones larger than $2.8 \mathrm{~mm}$ ML but gill photophores were observed only on ones larger than 4.6 mm ML.

When eye photophores were examined on the smallest specimens (1.5 $\mathrm{mm} \mathrm{ML})$ a photophore was seen in the ventral eye. On the specimens of 2.8-3.1 $\mathrm{mm}$ ML four photophores of the same size in a linear fashion were observed. On specimens of 3.8-4.6 $\mathrm{mm}$ ML six with the same characteristic were observed. On specimens with $6.6 \mathrm{~mm}$ ML nine photophores with different sizes on a line were observed. However on ones with $8.3 \mathrm{~mm} \mathrm{ML}$, ten photophores with various sizes and similar lining characteristics as adults have were observed (Fig. 3).
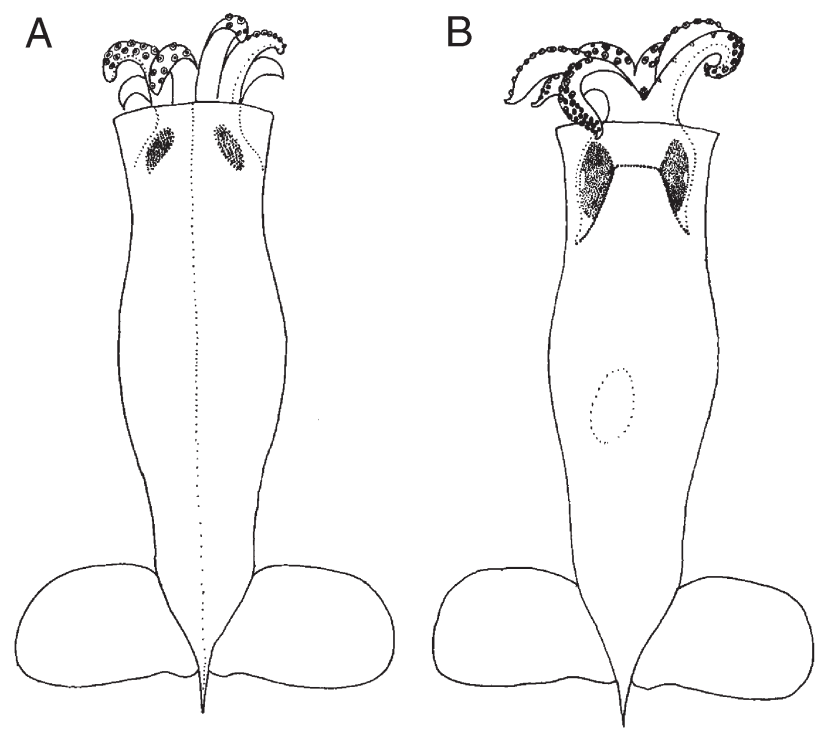

FIG. 4. - Onychoteuthis banksii $\mathrm{ML}=5.0 \mathrm{~mm}$ (A: dorsal view, B: ventral view). 


\section{Family ONYCHOTEUTHIDAE \\ Unidentified larvae}

One specimen with a $5 \mathrm{~mm}$ ML was collected from $650 \mathrm{~m}$ in the northern Aegean (Table 1, Fig. 4).

There are two recognised Onychoteuthidae specimens in the Mediterranean, Ancistroteuthis lichtensteinii and Onychoteuthis banksii (Mangold and Boletzky, 1987). According to Sweeney et al. (1992) these two are indistinguishable at a size smaller than $11 \mathrm{~mm}$ ML. Lefkaditou et al. (1999) reported a specimen with a $7.5 \mathrm{~mm} \mathrm{ML}$ at $1000 \mathrm{~m}$ in the northern Aegean as an unidentified larva of the Onychoteuthidae family. In addition, Lefkaditou et al. (1999) stated the possibility that this larva may be a member of the $O$. banksii species referring to the reports made by Degner (1925) and Roper (1974) from the eastern Mediterranean (east of $23^{\circ}$ ), in agreement with our findings.

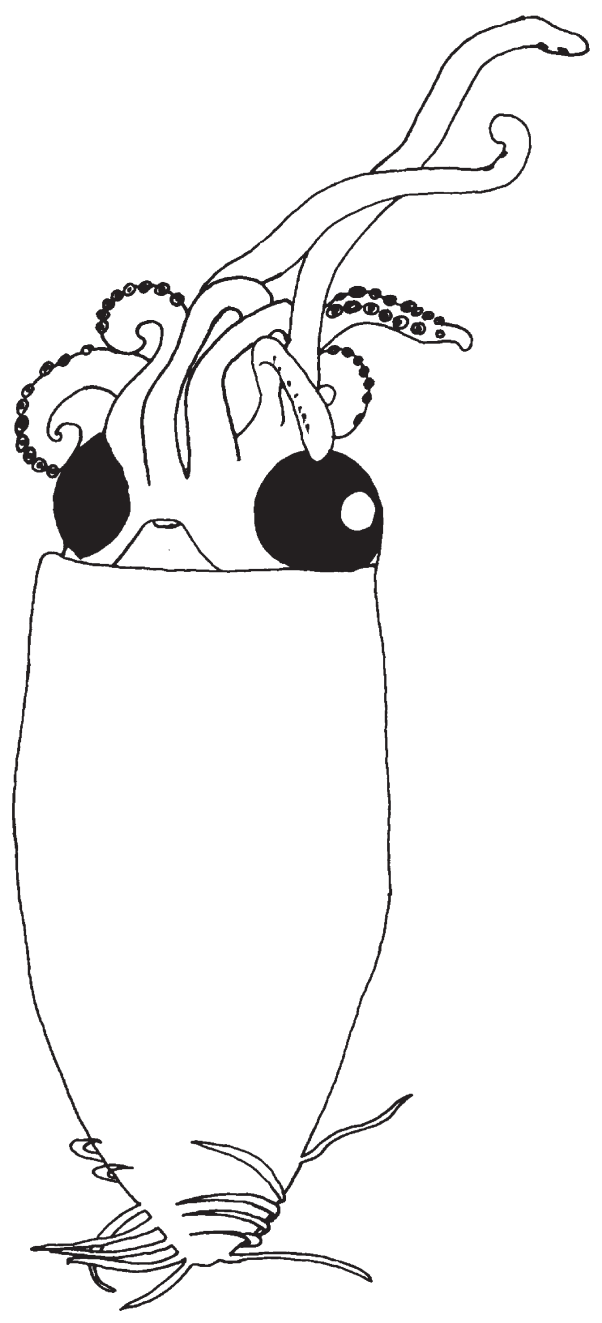

FIG. 5. - Chtenopteryx sicula $\mathrm{ML}=9.0 \mathrm{~mm}$ ventral view.
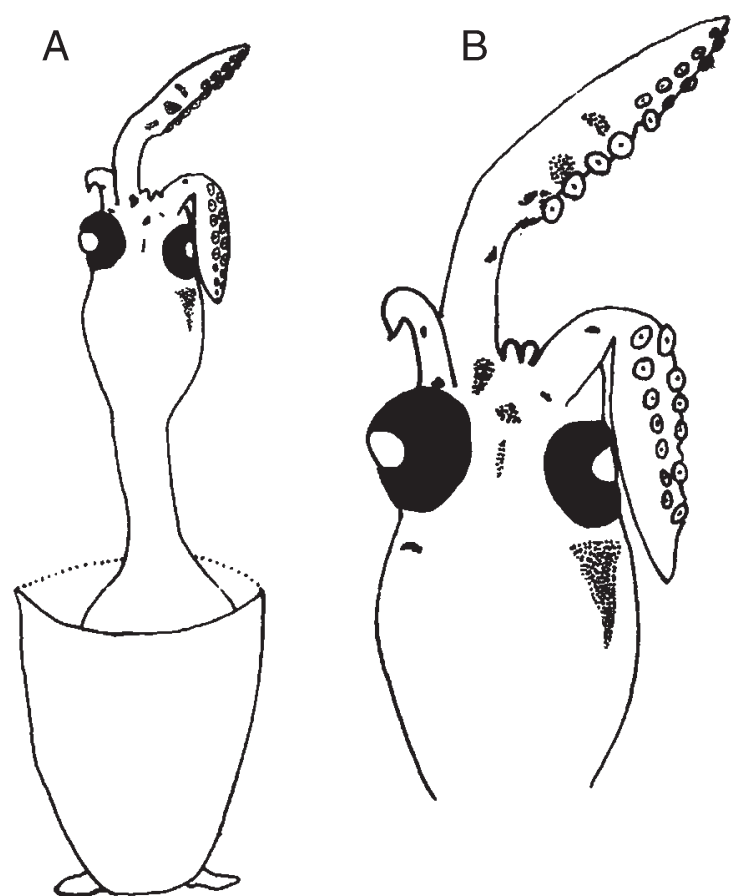

FIG. 6. - Brachioteuthis riseii $\mathrm{ML}=3.5 \mathrm{~mm}$ (A: general view, B: view of the head and arms).

Family HistioteUtHIDAE

Histioteuthis bonnellii (Férussac, 1834)

One specimen (10 mm ML) was found at $100 \mathrm{~m}$ in the northern Aegean (Table 1).

\section{Histioteuthis reversa (Verrill, 1880)}

Two specimens (1.6-5.0 $\mathrm{mm} \mathrm{ML)} \mathrm{were} \mathrm{found} \mathrm{at}$ $100 \mathrm{~m}$ in the northern Aegean (Table 1)

\section{Family CHTENOPTERYGIDAE \\ Chtenopteryx sicula (Verany, 1851)}

A specimen of this species with $9.0 \mathrm{~mm}$ ML was collected in the northern Aegean at $100 \mathrm{~m}$ (Table 1, Fig. 5). A juvenile specimen of this species is being reported for the first time from the Aegean Sea.

Family BRACHIOTEUTHIDAE

Brachioteuthis riisei (Steenstrup, 1882)

One specimen (3.5 mm ML) was found at $500 \mathrm{~m}$ in the northern Aegean (Table 1, Fig. 6). A juvenile specimen of this species is being reported for the first time from the Aegean Sea. 


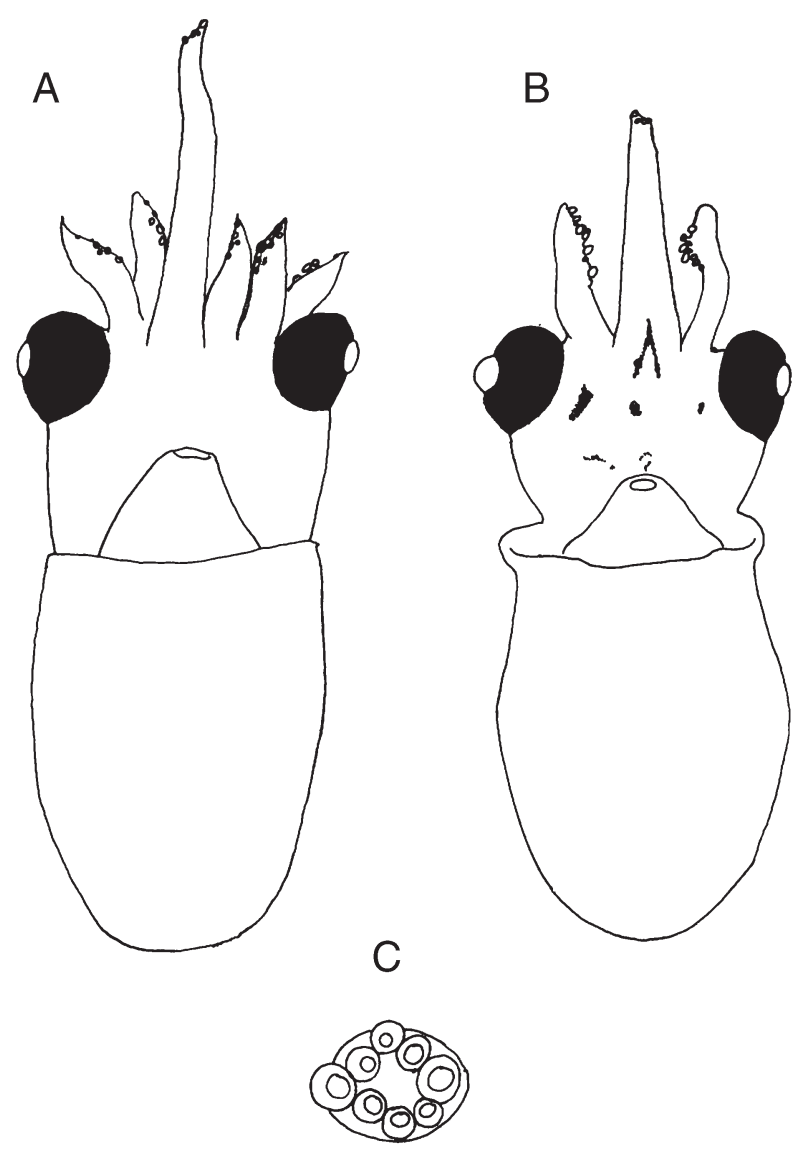

FIG. 7. - Illex coindetii A: $2.5 \mathrm{~mm}$ ML; B: $5.3 \mathrm{~mm}$ ML; C: view of proboscis suckers.

\section{Family OMMASTREPHIDAE}

Illex coindetii (Verany, 1839)

Eight specimens of this species, two from the northern Aegean and six from the southern Aegean, were obtained. Samples from the northern Aegean of $2.5 \mathrm{~mm}$ ML were gathered from $650 \mathrm{~m}$. From the southern Aegean, two samples with 2.1-3.3 mm ML were collected from $100 \mathrm{~m}$ and four with 1.6-5.3 $\mathrm{mm}$ ML were collected from $650 \mathrm{~m}$. It was observed that the lengths of proboscis suckers were almost the same (Fig. 7).

Juveniles of this species are being reported for the first time from the Aegean Sea.

\section{Family THYSANOTEUTHIDAE}

Thysanoteuthis rhombus Troschel, 1857

One specimen with a ML of $2.5 \mathrm{~mm}$ was collected from a depth of $350 \mathrm{~m}$ in the northern Aegean (Table 1, Fig. 8). A juvenile specimen of this species is being reported for the first time from the Aegean Sea.
Family CHIROTEUTHIDAE

Chiroteuthis veranii (Férussac, 1835)

A specimen of this species was collected from 650 $\mathrm{m}$ in the southern Aegean (Table 1). The mantle length of this specimen was measured as $54.0 \mathrm{~mm}$ ML.

\section{Order OCTOPODIDA \\ Suborder INCIRRINA \\ Family OCTOPODIDAE \\ Subfamily OcTOPODINAE \\ Octopus vulgaris Cuvier, 1797}

Twenty-two specimens of this species were collected, which proves it to be the second most abundant species. One of the specimens with $3.0 \mathrm{~mm} \mathrm{ML}$ was collected from $650 \mathrm{~m}$ in the northern Aegean and the remaining of 21 with ML's varying between 1.2-5.1 $\mathrm{mm}$ were collected from all contours of depths in both parts (Table 1, Fig. 9).

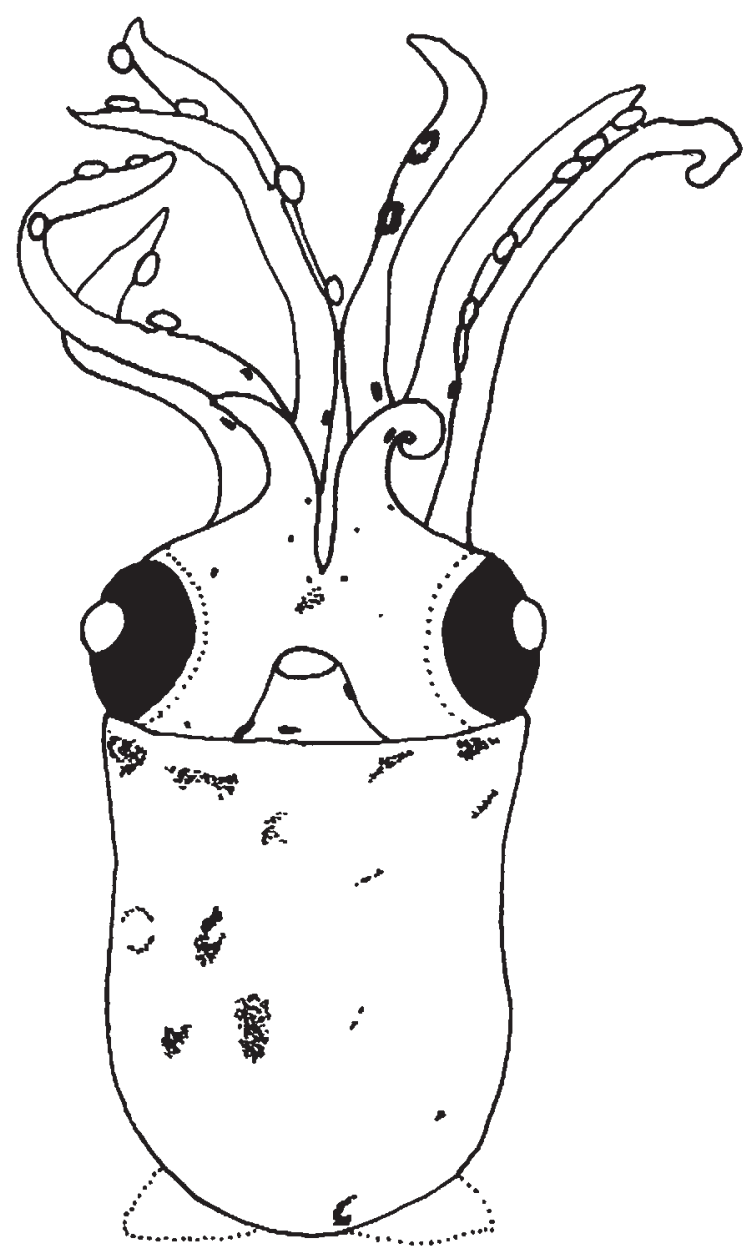

FIG. 8. - Thysanoteuthis rhombus, $\mathrm{ML}=2.5 \mathrm{~mm}$, ventral view. 

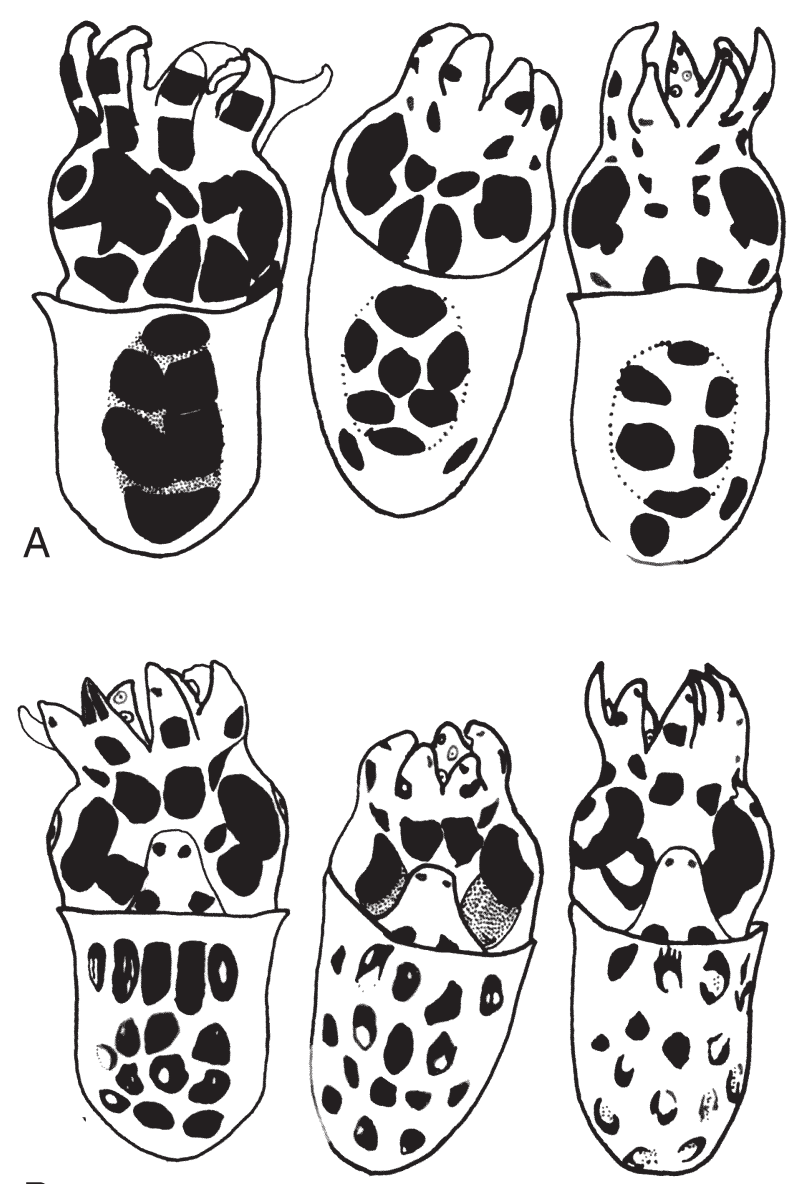

B

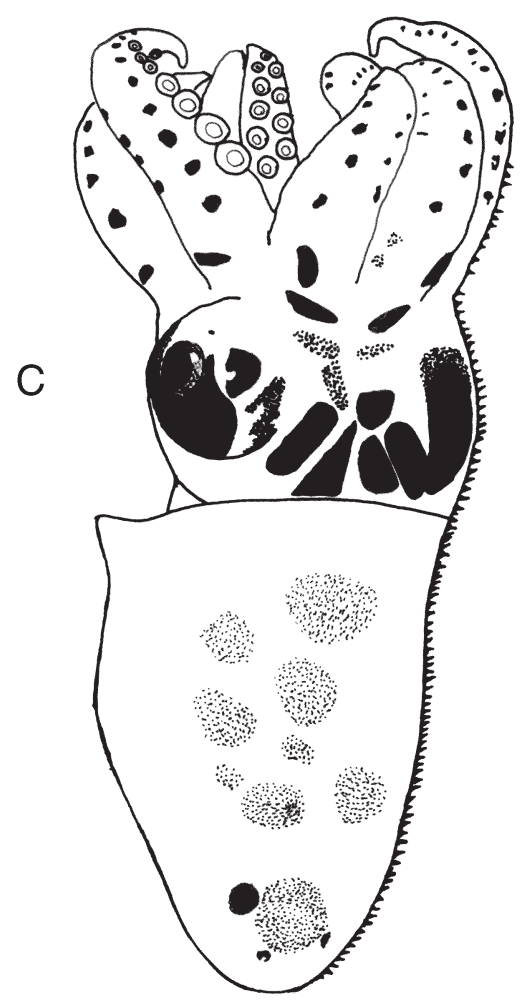

FIG. 9. - Different pigmentation views of Octopus vulgaris larvae (A: dorsal view, $B$ : ventral view $M L=2.5 \mathrm{~mm}, \mathrm{C}: \mathrm{ML}=5.1 \mathrm{~mm}$ ).

\section{Subfamily ELEDONINAE \\ Eledone cirrhosa (Lamarck, 1798)}

One specimen (2.5 mm ML) was found at $650 \mathrm{~m}$ in the northern Aegean (Table 1).

\section{Family ARGONAUTIDAE Argonauta argo Linnaeus, 1758}

One specimen ( $2.5 \mathrm{~mm} \mathrm{ML}$ ) was found at $100 \mathrm{~m}$ in the southern Aegean. A juvenile specimen of this species is being reported for the first time from the Aegean Sea.

\section{The abundance and vertical distribution of species}

When the distribution of juvenile cephalopods in the two different sections of the Aegean Sea is compared, it is observed that the north is richer in diversity, with ten species, than the south is, with 8 species. On the other hand, in the aspect of quantity the southern Aegean is higher in proportion by 72 to $28 \%$ (Table 1). Studies on the vertical distribution of sampled specimens showed that $41 \%$ of the species were at $350 \mathrm{~m}, 38 \%$ of the species were at $650 \mathrm{~m}$ and $21 \%$ of the species were at $100 \mathrm{~m}$ (Table 1 ).

When the Aegean is examined separately as north and south, it is seen that an increase in cephalopod abundance occurs at increasing depths in the northern Aegean, whereas in the south it first increases but later decreases at deeper levels (Table 1).

When the abundance of juvenile cephalopods was investigated in different periods of sunlight, over the whole Aegean the least quantity was 15 specimens at sunrise, whereas it was greatest with 36 specimens at midnight. According to vertical investigations for their distributions, the number of specimens at a depth of $100 \mathrm{~m}$ increases from sunrise until noon and than decreases from noon to midnight. At $350 \mathrm{~m}$ a constant increase was observed from sunrise until midnight. At $650 \mathrm{~m}$, however an increase was observed from sunrise to noon then a decrease in the evening and another increase at midnight (Table 2).

\section{DISCUSSION}

The first records of juvenile cephalopods of the Aegean pelagic ecosystem were given by Degner (1925). Degner found juveniles of six cephalopod 
species (Heteroteuthis dispar, Onychoteuthis banksii, Gonatus fabricii, Abraliopsis morisi, Eledone sp. Scaeurgus unicirrhus). Among these species $G$. fabricii may be wrongly identified because there is no other occasion of an adult Gonatus being reported in the courses of all research carried out after Degner (1925) in the Mediterranean. Juveniles reported as Eledone spp. are considered to be E. cirrhosa. This is because E. moschata, which is one of the two Eledone species in Mediterranean, is not found in the pelagic zone in any stage of its life including juvenile ages (Sweeney et al., 1992).

A second study in the same area was carried out by Lefkaditou et al. (1999) and 9 juvenile cephalopod species were reported from the northern Aegean (Heteroteuthis dispar, Octopus salutii, O. vulgaris, Histioteuthis reversa, $H$. bonnellii, Pyroteuthis margaritifera, Ancistrocheirus lesueurii, Chiroteuthis veranii, Onychoteuthis sp.)

In this study five of the fourteen species identified were recorded for the first time in the Aegean Sea (Chtenopteryx sicula, Brachioteuthis riisei, Illex cf. coindetii, Thysanoteuthis rhombus, Argonauta argo) as juvenile cephalopods. Sampling which was conducted in four time periods (early morning, noon, late evening and midnight) showed that the caught juvenile and larval cephalopods were more abundant at 350-650 meters. This points to a vertical distribution in larval cephalopods that is dependent on light (Table 2).

When samples were classified in the aspect of abundance it was found that Heteroteuthis dispar is dominant in the northern Aegean with 50\%, in the southern Aegean with 41.7\%, and in the whole Aegean with $44 \%$. Octopus vulgaris follows with $22 \%$. The vertical abundance of all species was the greatest at 350-650 m levels.

The only sepiolid species $H$. dispar retrieved in our research was first reported by Degner (1925). Lefkaditou et al. (1999) also reported 27 specimens of $H$. dispar with mantle lengths varying between 2.0 and $7.0 \mathrm{~mm}$ at 250, 500 and $750 \mathrm{~m}$. Lefkaditou added that this species composed $60 \%$ of the whole catch of juvenile cephalopods and was most crowded at $250 \mathrm{~m}$ levels with a decreasing in number towards deeper levels.

These results, in conjuction with our results, prove that (Table 1) juvenile populations of $H$. dispar are dense exist just below epipelagic levels. Differences emerge from the different depths of studies. Smaller individuals of this species are found at deeper levels, whereas larger ones are found at lev- els closer to the surface (Fig. 2). These results are consistent with those of Clarke (1969) who studied in the Canary Islands, and Lefkaditou et al. (1999), who studied in the Aegean Sea.

A juvenile of Ancistrocheirus lesueurii with 2.5 mm length was obtained at $350 \mathrm{~m}$ depth in the southern Aegean. Previously one with a length of 5 $\mathrm{mm}$ ML had also been reported by Lefkaditou et al. (1999) in the north Aegean at $250 \mathrm{~m}$ depth.

P. margaritifera, a juvenile of which was reported by Lefkaditou (1999) (20.0 mm ML) at $500 \mathrm{~m}$ depth in the northern Aegean, was collected at all depth zones in our study. This result shows similarities with Roper's (1974) results in the Mediterranean. In addition, Vecchione (1987) reports three references for Pyroteuthis margaritifera ontogenetic vertical migration, one of which shows a descent pattern (see also Table 1).

Only one specimen of $H$. bonnellii with $10.0 \mathrm{~mm}$ ML was sampled at $100 \mathrm{~m}$ depth in our study. Lefkaditou et al. (1999) sampled a species with $21 \mathrm{~mm}$ ML at the $500 \mathrm{~m}$ zone. According to Voss et al. (1992) $H$. bonnellii specimens with a mantle length of 10-20 mm were found at 100-200 m depths, while juvenile and sub adults with a mantle length exceeding $20 \mathrm{~mm}$ were found between 200 and $800 \mathrm{~m}$. Therefore, our findings on the vertical distribution of $H$. bonnellii in the Aegean Sea are in agreement with Voss et al. (1992).

Another histioteuthid, $H$. reversa was found in our research in the northern Aegean at $100 \mathrm{~m}$ depth. Lefkaditou et al. (1999), who worked in the same area, sampled this species at 250, 500, 750 and 1000 $\mathrm{m}$ depths. This supports the findings of Voss et al. (1992), who report that members of this species may be found in all depth zones from the surface to 1000 $\mathrm{m}$ or deeper.

Chtenopteryx sicula, which was observed for the first time in the Aegean Sea as a juvenile, was previously reported by Degner (1925) as Ctenopteryx siculus in the eastern Mediterranean at $300 \mathrm{~m}$ zone. Mangold and Boletzky (1987) stated that the life cycle of this species is completed entirely within the 0-500 m zone.

The juvenile Brachioteuthis riisei sampled from the north Aegean at $500 \mathrm{~m}$ is a new record from the Aegean. A juvenile with a $25 \mathrm{~mm}$ ML was previously reported from the Mediterranean at $300 \mathrm{~m}$ depth by Degner (1925). According to Mangold and Boletzky (1987) this species has a distribution from the surface to 500 metres in the whole Mediterranean except the Aegean Sea. 
While Vecchione (1987) and Sweeney at al (1992) observed juveniles of this species distributed in surface waters, the present observations are in agreement with those of Thysanoteuthis rhombus by Mangold and Boletzky (1987), who reported a broad distribution depth range, the lower limits of which are not known.

Chiroteuthis veranii sampled in our research at $650 \mathrm{~m}$ depth was previously reported from the Marmara Sea at $1500 \mathrm{~m}$ under the name $C$. verany by Degner (1925). Four specimens with 16-31 mm ML were reported from the northern Aegean at 250 and $750 \mathrm{~m}$ zones by Lefkaditou et al. (1999). All findings show that this species occurs in mesopelagic and bathypelagic zones, as reported by Mangold and Boletzky (1987).

Octopus vulgaris was reported from the northern Aegean at $750 \mathrm{~m}$ by Lefkaditou et al. (1999). In our study it was sampled in the same area at $650 \mathrm{~m}$ depth. However in the southern Aegean the same species was sampled at 100,350 and $650 \mathrm{~m}$. It is known that the species, though being mostly related to the continental shelf areas (down to $200 \mathrm{~m}$ depth), can also be found on deeper bottoms (MangoldWirz, 1963; Sanchez, 1986). Moreover, juveniles being planktonic, the depth range of their distribution is not strictly related to adult habitats. For instance, larvae of planctonic species were found at $1000 \mathrm{~m}$ around Sardinia Island and at $400 \mathrm{~m}$ in the Marmara Sea by Degner (1925).

A juvenile of E. cirrhosa retrieved from the northern Aegean at $650 \mathrm{~m}$ is being reported for the first time. Degner (1925) sampled some juveniles of this species in the eastern Mediterranean but he did not distinguish whether they were E. moschata or $E$. cirrhosa. In results of studies carried out by Salman et al. (2000) on adults, it was observed that E. cirrhosa in the northern Aegean was found abundantly down to a depth of $500 \mathrm{~m}$, whereas E. moschata distribution was limited to a maximum depth of $200 \mathrm{~m}$ zone.

Another first time report for the Aegean Sea is that a juvenile of Argonauta argo, an epipelagic species that lives in surface waters, was obtained at $100 \mathrm{~m}$ depth. Such a report was previously made by Degner (1925) and Roper (1974) from the Mediterranean.

When vertical distribution of all the 14 species retrieved in this work is analyzed, as Roper (1974) stated A. argo juveniles show distributions in the epipelagic zone in the Aegean Sea. When the results of our study and others (Degner, 1925; Roper, 1974;
Sweeney et al., 1992; Lefkaditou et al., 1999) are evaluated together, with the exception of the controversy observed in the distribution of T. rhombus, the remaining of eleven species show a broader vertical distribution.

Mangold and Boletzky (1987) reported a total of 40 cephalopod species from the Aegean Sea, which has increased to 50 with later studies (i.e. D'Onghia et al., 1991; Katagan et al., 1992; Vardala-Theodorou et al., 1991; Salman et al., 1999).

Among 14 species retrieved during this study, $O$. vulgaris and E. cirrhosa are benthic as adults, Illex coindetii is pelagic and semi-demersal, and the remaining eleven are pelagic. When life cycles of recognised species that compose the Aegean cephalopod fauna are examined, it is seen that almost 30 of these species exist in the pelagic ecosystem during their juvenile phase.

As a result, juvenile cephalopods of the Aegean pelagic ecosystem are rich in diversity in the northern Aegean, but rich in quantity in the southern Aegean. Consequently, in order to clarify the definition of juvenile cephalopod species, their abundance, growth and vertical distribution, seasonal samplings in particular should be considered as further studies.

\section{ACKNOWLEDGEMENT}

We are indebted to Mr Murat Nurlu for improving the English of the text and to Mr. Bahadir Önsoy for illustrations.

\section{REFERENCES}

Amaratunga, T. - 1983. The role of Cephalopods in the marine ecosystem. In: J.F. Caddy (ed.), Advances in assessment of world Cephalopods resources. FAO Fish. Tech. Rap. 231: 379-415.

Bello, G. - 1986. Catalogo dei Molluschi Cephalopodi Viventi nel Mediterraneo. Boll. Malacologico., 22(9-12): 197-214.

Bello, G. - 1990. The Cephalopod fauna of the Adriatic. Acta Adriat., 31(1/2): 275-291.

Chun, C. - 1910. Die Cephalopoden. 1 Oegopsida. Wiss. Ergeb. Dtsch. Tielfsee-exped. "VALDIVIA", 18: 410 p.

Clarke, M.R. - 1969. Cephalopoda collected on the Sound cruise. J. Mar. Biol. Ass. U.K. 49: 961-976.

Degner, E. - 1925. Cephalopoda. Report on the Danish Oceanographic Expeditions 1908-10 to the Mediterranean and adjacent seas, 9: Vol. II. Biology, C. 1. pp. 1- 94.

D’Onghia., G., A. Mataresse, A. Tursi and P. Maiorano. - 1996. Cephalopods collected by bottom tawling in the North Aegean Sea (Eastern Mediterranean). Oebelia 22: 33-46.

D'Onghia., G., A. Tursi, C. Papaconstantinou and A. Mataresse. 1991. Teuthofauna of the North Aegean Sea: Preliminary result on catch, composition and ditribution. FAO Fish. Rep. No. 477: 69-84.

Katagan, T. and A. Kocatas. - 1990. Note préliminaire sur les céphalopodes des eaux Turques. Rapp. Comm.Int. Mer Méditerr. 32: 242. 
Katagan, T., A. Salman and H.A. Benli. - 1992. Nouvelles observations sur Ommastrephes bartrami (Lesueur, 1821) (Cephalopoda, Ommastrephidae) dans le Bassin Méditerranéen Oriental. Rapp. Comm. Int. Mér Méditerr. 33: 298.

Kocatas, A. and N. Bilecik. - 1992. Aegean Sea and Its Living Resources. T.C. Tarim ve Köyisleri Bakanligi. Su Ürünleri Arastirma Enstitüsü Müdürlügü. Bodrum. Seri A. 7: 88 pp. (in Turkish)

Lefkaditou, E., C. Papaconstatinou and K. Anastasopoulou. - 1999. Juvenil cephalopods collected in the midwatwer macroplancton over a trench in the Aegean Sea (Northeastern Mediterranean). Isr. J. Zool. 45: 395-405.

Mangold, K. and S.V. Boletzky. - 1987. Céphalopodes. In: Fischer, W., M.L. Bauchot, and M. Schneider (eds.), Fiches d'identification des espèces pour les besoin de la pêche. (Révision 1) Méditerrané et Mer Noire. Vol. I. FAO, Rome, pp. 633-714.

Mangold-Wirz, K. - 1963. Biologie des céphalopodes bentiques et nectoniques de la mer Catalane. Vie Millieu, Suppl. 13: 1-285.

Naef, A. - 1923. Die Cephalopoden (Systematik). Fauna Flora Golf. Neapel, 35 Monogr. I/1: 1-863. (Translated by A. Mercado, 1972. Smithsonian Institution, Washington, 917 p.)

Orsi-Relini, L., F. Garibaldi, G. Palandri, and C. Cima. - 1994. La comunita mesopelagica e i predatori "di superficie". Biol. Mar. Méditerr., 1: 105-112.

Roper, C.F.E. - 1974. Vertical and seasonal distribution of pelagic cephalopods in the Mediterranean sea. Preliminary report. Bull. Am. Malacol. Union.: 27-30.

Salman, A., T. Katagan and H.A.Benli. - 1997. Bottom trawl teuthofauna of the Aegean Sea. Arch. Fish. Mar. Res., 45: 183-196.

Salman, A., T. Katagan and S.V. Boletzky. - 1999. New cephalopod molluscs in the eastern Mediterranean: Previously unnoted species or Lessepsian migrants? Vie Milieu, 49(1): 11-17

Salman, A., T. Katagan and A.C. Gücü. - 2000. The distribution and fishing of two Mediterranean Eledone spp. (Octopoda:
Cephalopoda) in the Aegean Sea. Tr. J. Zoolgy., 24: 165-171.

Sanchez, P. - 1986. Distribucion batimétricia y abundancia algunos cefalopodos del mar Catalan. Inv. Pesq., 50(2): 237-345.

Sanchez, P. and B. Moli. - 1985. An annotated list of Cephalopod larvae collected off the Mediterranean coast of Spain, 19761981. Vie Milieu, 35: 171-173.

Stergiou, K.I., E.D. Christou, D. Georgopoulos, A. Zenetos and C. Souvermezoglou. - 1997. The Hellenic Seas: physics, chemistry, biology and fisheries. Oceanogr. Mar. Biol. Annu. Rev., 35: 415-538.

Sokal, P.R. and Rohlf, F.J. - 1980. Biometry. W.H. Fremann and Company, New York. 859 pp.

Sweeney, M.J. and C.F.E. Roper. - 1998. Classification, type localities and type repositories of recent Cephalopods. In: N.A. Voss et al., (eds.), Systematics and Biogeography of Cephalopods. Smithson. Contrib. Zool. 586: 561-599.

Sweeney, M.J., C.F.E. Roper, K.M. Mangold, M.R. Clarke and S.V. Boletzky. - 1992. "Larval" and juvenile Cephalopods: A manual for their identification. Smithson. Contrib. Zool. 513: $282 \mathrm{pp}$.

Vardala-Theodorou, E., P. Giamas and A. Dimitropoulos. - 1991. A short notice on the occurrence of a pair of Thysanoteuthis rhombus Troschel, 1857 in Southern Euboic Gulf. Boll. Malacol. 27: 25-34

Vecchione, M. - 1987. Juvenile Ecology. In: P.R. Boyle (ed.), Cephalopoda life cycles, Vol. II. Academic Press, London. pp. 61-84.

Voss, N.A., S.J. Stephen and Zh.Dong. - 1992. Histioteuthidae. In: M.J. Sweeney, C.F.E. Roper, K.M. Mangold, M.R. Clarke and S.V. Boletzky (eds.), "Larval" and juvenile Cephalopods: A manual for their identification. Smithson. Contrib. Zool. 513: 73-91.

Scient. ed.: P. Sánchez 